\title{
7. Policing the Elections in Chimbu Province
}

\author{
Thomson Fafungian
}

National elections in Papua New Guinea, particularly the Highlands Region, are something that people look forward to - the educated elite, community leaders, churches, businessmen and village people alike. Elections are a time when money, pork and beer flow into the province and everyone wants to participate. This gifting culture started on a large scale in the 1982 national election in Chimbu Province when Sir Iambakey Okuk bought 34 pallets (3400 cartoons) of beer from the SP Brewery for the Simbu people to consume as part of his election campaign. During this drinking spree people ran amok in the town and there was total chaos. The police arrested so many people the police cells were full, yet Kundiawa town was still full of drunkards who caused considerable violence, and the police could not do much. The 1982 election was a learning experience for the police, and since then they have sought to make thorough preparations for elections. The extent of gifting in Chimbu has meant elections are not fair or free, but are characterized by corruption, bribery, threats, and false promises by desperate candidates hungry for fame, power and glory. Campaign houses built by candidates to distribute food and money and conduct all sorts of illegal activities have proliferated throughout the Highlands Region. This kind of corruption reached its peak in the 2002 election.

This chapter is based on my personal involvement and experience during the 2007 election. It covers the pre-election, polling and post-polling periods. It does not necessarily represent the Royal Papua New Guinea Constabulary's view on the management and running of the election but is my own personal assessment as someone involved in all aspects of election security.

The Royal Papua New Guinea Constabulary (RPNGC) saw this event as a major operation for the constabulary. As set down in the commissioner's mission statement, all the provincial police commanders (PPCs) were responsible for ensuring 'a safe, secure, fair, democratic election' and for planning and executing the RPNGC's mission in their provinces. In Chimbu Province, the PPC, Superintendent Joseph Tondop, was the man responsible.

In Chimbu Province police were involved in the preparation, polling, counting and post-election phases. The PPC's planning was complemented by my proposal to secure Australian Agency for International Development (AusAID) funding through the Electoral Support Program (ESP) and consolidate a partnership with 
civil society groups, churches, the Papua New Guinea Electoral Commission (PNGEC) and the Provincial AIDS Council in carrying out civic, HIV/AIDS, and law and order awareness in preparation for the election. The planning and security in the pre-polling operations and the counting involved Papua New Guinea Defence Force (PNGDF) personnel and Correctional Services members. The post-election management of tribal fights and disruption of government services in the districts as a direct result of election-related violence was included in the plan.

\section{Civic and law and order awareness}

Chimbu Province has had its share of violence and disorder during past elections. Violence has occurred in all six districts. The scars are visible from the roadside. For example, as one drives into Migendi Catholic Mission Station one can see the valley extending towards the Wahgi River: what was once a flourishing valley was destroyed during post-election violence between supporters of two losing candidates in the 1997 election, Peter Kuman and John Nopro. Across the province thousands of kina worth of property have been destroyed, villages have completely disappeared, food and coffee gardens have been destroyed, and people killed and injured, including innocent women and children. Indeed, past elections have taken such a toll that thousands of displaced people are now living in informal settlements in and around Kundiawa or have moved to other provinces because their homes and livelihoods have been destroyed by electionrelated violence.

Police security during elections has typically been focused on the polling days only, with the greater part of the police effort put into ensuring adequate logistics and manpower at polling locations. Our main focus has been the security of ballot papers. This has meant that once polling was completed the police would move out with the papers, leaving innocent men, women and children to suffer at the hands of losing candidates and their supporters. In my experience, the violence usually starts after polling, and in many cases after the counting is complete. The release of the final results often triggers the violence. Unfortunately, with limited resources police cannot be in the villages at all times, and cannot ensure the security of the people in the post-election period. The police do not have the capacity to contain violence when it occurs on a large scale throughout the province, and this often happens once the declarations are made.

In the lead-up to the 2007 election, however, the PPC at the time, Superintendent Jimmy Onopia, resolved to take a more proactive approach in the hope of reducing the level of violence in the province. This involved drug reduction awareness and law and order awareness. He knew very well that the reactive 
policing measures typically employed did not achieve much when there was widespread violence. Police in other provinces shared the PPC's concerns and had similar intentions but were constrained in implementing their ideas by funding and procedures.

Police in Papua New Guinea are faced with financial constraints at the best of times; the pressures of a general election exacerbate this. There was, for example, no money allocated to community policing for awareness before the 2007 election. Realizing this, I put forward a community policing proposal to the ESP Phase 2 and fortunately my application was approved. I also thought that community awareness about elections might help make the job of policing elections easier, as the community itself needed to start taking on board the laws designed to make elections free and fair. I was assisted and advised by Dr Nicole Haley (research fellow, State, Society and Governance in Melanesia Program, The Australian National University) whom I met during the KorobaLake Kopiago by-election in 2006 when I was deployed as security contingent commander for polling in the Kopiago Local-Level Government (LLG) area, and by Ms Susan Ferguson (communication adviser, ESP).

The law and order awareness program came under the community awareness component of the AusAID-funded ESP, but because it was trying to make strategic links with police it was moved into the planning and operations area of ESP, where it was supported by Peter Pascoe, the police liaison adviser. Susan Ferguson maintained links with the program since, as a pilot project, it had implications across the entire awareness program. The proposal was approved for funding in late December 2006.

I put forward the proposal for community policing as I believed it could reduce election-related violence and make for a fair and peaceful election and demonstrate how the community, the PNGEC, civil society groups, and the police could work in partnership to carry out an awareness campaign and enable the people to claim ownership of the election. The ESP was interested in working with the police, since the police are an important part of the election process - and sometimes part of the problem.

I organized a team of people to run the project, selected from police and civil society organizations. These included Meri I Kirap Sapotim, the Community Development Scheme, the Provincial AIDS Council, community leaders from all around the Chimbu Province, as well as the PNGEC. The team was made up of 50 police personnel (47 men and 3 women) from across the province, 12 Chimbu-based Meri I Kirap Sapotim members (5 men and 7 women), 8 Community Development Scheme members (7 men and 1 woman), 4 provincial AIDS educators ( 2 men and 2 women), 18 community leaders (all men) and 3 returning officers (all men). In all, some 95 personnel were involved. The 
partnership was coordinated and managed by me with the assistance of Pauline Kenna, a human rights lawyer. Her involvement in this project earned her the Papua New Guinea Woman of the Year for 2007 and a major Westpac prize. Other civil society organization members, such as Steven Gari, James Kalyale and Pastor Solomon Minga, gave technical advice.

Before the teams were sent out to run awareness in the districts, all the members attended a week-long ESP training course. The training was conducted using the ESP training manual. I wrote extra material for the police about electionrelated law and their role in enforcing the law. I also wrote material for them concerning police conduct, particularly what was expected of them during the election. Further to this, all members of the team agreed to abide by a code of conduct during the training. The code of conduct made clear the kind of behaviour expected of everyone.

Civics education was vital as it informed the team members about the laws concerning the illegal practices that were common in all voting places. It told the police about their role during the election and called on them to display a high level of discipline and to be firm and fair in providing election security. It educated the public about the rights of women to vote freely and safely. The people were taught about the new limited preferential voting (LPV) system and how to vote correctly on the polling day. The awareness promoted democracy and the importance of a good and accurate electoral roll for people when voting. It also informed people about the risk of HIV/AIDS infection during elections.

All the police who attended the training responded favourably. Many wished they had had this civic and governance education a long time ago. Importantly, I observed that it gave them both the motivation to go out into the field and the skills and knowledge to run the awareness.

Our awareness started with an official launching in Kundiawa (the main town of Chimbu Province). Following this, messages were sent out to all the districts for the people to prepare to meet the team. The launch attracted about 2000 people and was a good way to demonstrate to the people that the police and other leaders thought this was important.

During the awareness, the teams went far and wide, covering all corners of the province, reaching about 80,000 people. Sixty candidates attended our awareness, as did thousands of people who are illiterate and have no access to schools or media. In Karamui alone, 70 percent are illiterate.

The awareness ended before the writs were open as it was too dangerous to run such awareness during the campaign period. It was conducted for three months commencing February and ending March 2007. Its aim was to prepare people to think and act properly and not get misled by candidates. 
Establishing the partnership helped in the sharing of resources and expertise. Police allocated a full-time vehicle; the Provincial AIDS Council provided AIDS educators and materials; civil society groups provided skilled personnel and material, and the PNGEC provided awareness materials.

We carried out awareness district by district and managed to cover all ward areas. To do this we divided into four teams. All teams had police personnel, civil society personnel, AIDS educators and community leaders, as well as a mix of men and women to ensure better gender participation. Each of the partners had its own networks in the districts and these were used to reach out to the people.

As might be expected, there were many logistical difficulties in running a project of this kind, including bad weather, poor communications, poor roads, and remoteness. The weather presented many difficulties in that there was a lot of rain in the early part of the year. The majority of the awareness was undertaken by foot patrols, which walked long distances under frequently difficult conditions. All personnel were paid the same rate of allowance, regardless of whether they were public servants or volunteers. Protective clothing, boots, and sleeping bags were provided for them.

Our teams sought to educate the people on the law and order aspects of elections, particularly electoral offences and their penalties; much attention was given to illegal practices such as under-age voting, threatening or offensive behaviour at polling stations, intimidation, and hijacking of ballot papers. As regards governance, we focused on the roles and responsibilities of elected members of parliament, how to elect a good leader, the separation of powers, bribery and inducement by candidates and supporters, and the rights and responsibilities of voters on polling day. We also conducted HIV/AIDS awareness and informed people about election-related activities that might increase the risk of HIV transmission. We hoped that if people were better informed they would make better decisions during the campaign and polling periods. Generally, our awareness was very well received throughout the province. People in the remote districts claimed that they had never before seen police or public servants in their area; some even expressed resentment and said they would not to vote in the election. A similar protest occurred during the 2004 Chimbu Provincial byelection, when the Haia people of Karamui-Nomane electorate refused to vote and their ballot papers were sent back unused.

\section{Election security}

For the overall planning of the election, security was coordinated from the police headquarters in Kundiawa, in consultation with the PNGEC. PPCs provided 
intelligence briefings on their respective provinces. The management was particularly cautious after the failings of the 2002 national election. The 2002 election was very violent and was generally regarded as Papua New Guinea's worst election yet. People used every kind of fraud, voter intimidation, theft of ballot boxes, and violence, including rape, destruction of properties and murder. These actions marred the election in some parts of the country; the polls were declared failed in six electoral districts in the Southern Highlands. New elections in those electorates were held successfully in May 2003, with very little violence. Australia gave about K60 million for these supplementary elections. In part, the smooth running of the supplementary elections can be attributed to the huge security presence.

The purpose of the election security was to ensure that polling was conducted democratically, such that people could freely cast their votes without fear, intimidation or any form of threats by any person. It was to ensure that the ballot boxes and ballot papers were conveyed safely into polling locations and returned back safely to the designated lockup, protected at all times by armed security force personnel. Finally, the security was to ensure that counting was conducted transparently and legally, resulting in the declaration of a winner.

\section{Security planning}

The security planning for the province involved five stages. The planning process was at the critical stage of planning and implementation when the incumbent PPC, Superintendent Jimmy Onopia, was charged and suspended from duty. He was replaced by Superintendent Joseph Tondop two weeks before polling commenced, and it was under Tondop's command and control that planning was carried out and executed.

The first stage was intelligence gathering prior to the election. This was conducted by police intelligence officers. They gathered data from sources all around the province concerning arms build-up, people planning to hijack ballot boxes or destroy ballot papers, and destruction of road infrastructure into the districts. This enabled police to identify areas of high risk and low risk.

The second stage was the pre-election operation, which focused on high risk areas to create a safe environment for polling to be conducted fairly and democratically. The pre-election operation was carried out two weeks prior to the polling date in all districts. It focused on the intelligence gathered, and was a combined operation involving the police response unit and PNGDF personnel. Raids and searches were conducted in areas of known arms build-up around the province. Several successful operations were undertaken. In one, the home of Mathew Siune, the then sitting member for Kundiawa-Gembogl, was raided 
and searched. A rifle with full magazine and 400 SLR rounds was found and confiscated, and the then member was charged for possession of an unlicensed firearm and ammunition. ${ }^{1}$

The third planning stage concerned the deployment of response units and polling security. The response units consisted of the PNGDF and police mobile units. The deployment of security personal to polling booths for the six electorates of Chimbu Province was detailed from the main operation order prepared by the election management team in police headquarters. The response units, predeployed to the province a full two weeks prior to polling, came under the command of the PPC, who was the operations commander for the election. He decided where and when they were to be deployed. The PPC chose to deploy the response units to problematic and high risk areas. Their deployment to preelection operations enabled them to crack down on arms build-up areas for a trouble free election on the polling day. By contrast, deployment to general polling security came late: because there were not enough personnel to cover all provinces at once, they were rolled over from province to province and came into Chimbu Province after completion of polling in Southern Highlands, Enga and Western Highlands provinces.

The fourth planning stage covered security for the counting. This sensitive and high risk responsibility was given to the response units as it was considered that desperate candidates and their supporters could disrupt the counting by unlawful acts. The response units were to monitor the perimeters, inside and outside of the counting venue. They had to search counting officials, including the returning officers, before they entered the counting venue to make sure they were free of anything that might affect the counting. Armed personnel were to escort ballot boxes from the storage place into the counting venue. Local police personnel were barred from involvement in any duties close to the counting venue. This was strongly supported by the people of Chimbu, as local policemen were believed to have ties with certain candidates within the province. However, police managers such as the PPC and I were permitted access to the counting centre so that we could supervise the security operation.

The fifth planning stage concerned post-election operations, which were a major concern for the Highlands provinces. Response units and local units were put on standby so as to attend to any election-related violence. Hired helicopters were meant to be available to transport security personnel into remote locations not accessible except by air; however, after polling the helicopters were gone and security personnel found it difficult to get into these areas to address postelection violence.

1 Siune was later acquitted by Kundiawa Magistrate's Court, even though the firearm and ammunition were found in his possession. 


\section{Command structure}

Election security in Chimbu involved a combined effort by the RPNGC, the PNGDF, and the Correctional Services, but the police were responsible for the command structure.

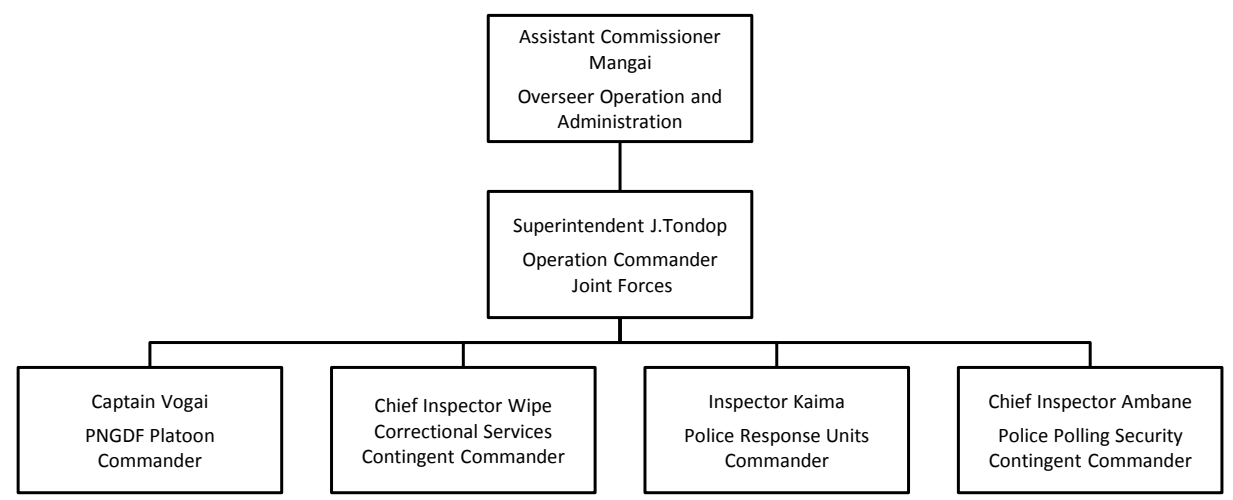

Figure 7.1: Command structure-Chimbu Province election security

Assistant Commissioner Mangae oversaw the entire election operation, while the Chimbu PPC, Joseph Tondop, commanded operations on the ground, issuing directions and orders to all subordinate officers. The PPC also headed the Provincial Election Steering Committee, which had an advisory and support role in facilitating the smooth flow of the election process and maintaining a positive working relationship with the provincial election manager, the Chimbu provincial administration and the joint forces commanders. The contingent commanders (police, PNGDF and Correctional Services) took charge of their respective districts in deployment and prioritizing command and control, reporting to the PPC for direction and assistance.

\section{Deployment of security}

The security units deployed to Chimbu Province, and their roles and responsibilities, are detailed in Tables 7.1 and 7.2. In total, 898 security personnel, including approximately 60-70 female officers were deployed.

I was security commander for Salt and Nomane LLG areas and took charge of one section of a PNGDF platoon (10 men), one section of a police mobile unit (10 men), 64 men Correctional Services personnel (including 6 women) and 10 police for polling security.

The area was categorized as high risk due to the build-up of firearms. Inserting my personnel proved problematic, due to remoteness and poor road conditions. 
The polling security were dropped off at Sinasina District and had to walk about 10 kilometres into Salt as none of the hired PNGEC vehicles was roadworthy. The response units were meant to be inserted by helicopter with the ballot papers, and waited at Kundiawa; unfortunately the helicopter was delayed for two days due to the rollover (it was extracting personnel from Western Highlands) and as a result the ballot papers and response units were left waiting in Kundiawa.

\section{Table 7.1: Deployed security units and their roles and responsibilities}

\begin{tabular}{ll}
\hline Units (type) & Number deployed \\
Response units (armed units) & \\
\hline Three police mobile squads & 90 men (30 men per squad) \\
One platoon of PNGDF & 35 men \\
\hline Polling security & \\
\hline PNG Correctional Services & 142 personnel, including some women \\
& $\begin{array}{l}\text { officers } \\
\text { Western Highlands provincial police polling }\end{array}$ \\
contingent & \\
National Capital District police reserve unit & 140 personnel, including about 8 women \\
Bomana police polling contingent & 172 personnel, including about 30 women \\
East Sepik police auxiliary & 172 personnel \\
Simbu provincial police polling contingent & 130 personnel, including about 6 women \\
\hline
\end{tabular}

\section{Table 7.2: District of deployment and responsibilities}

\begin{tabular}{lll}
\hline District & Security contingent/unit & Roles and responsibilities \\
\hline Kerowagi & Bomana police contingent & polling security \\
& squad of police mobile & deter violence \\
& section of PNGDF & deter violence \\
\hline Chuave & East Sepik auxiliary police & polling security \\
& squad of police mobile & deter violence \\
& section of PNGDF & deter violence \\
\hline Kundiawa-Gembogl & Western Highlands police & polling security \\
& squad of police mobile & deter violence \\
& section of PNGDF & deter violence \\
\hline Gumine & Western Highlands/Simbu police & polling security \\
& squad of police mobile & deter violence \\
& section of PNGDF & deter violence \\
\hline Sinasina-Yongomugl & NCD reserve police & polling security \\
& squad of police mobile & deter violence \\
& platoon of PNGDF (from Mt Hagen) & deter violence \\
\hline Karamui-Nomane & PNG CS contingent & polling security \\
& section of police mobile & deter violence \\
& section of PNGDF & deter violence \\
\hline
\end{tabular}


As Salt LLG is closest to Kundiawa, and thus most accessible, it was selected as the location for the command post to cover both Salt and Nomane LLG areas. There I observed the candidates discussing with the two assistant returning officers where polling locations were to be. The returning officers proved unable to make a firm decision in accordance with set procedures and gazettal. I stepped in and made a decision for them to avoid complications. Candidates and supporters issued threats and caused problems. One candidate, Michael Korry (who is owner of a security business in Port Moresby), rammed his vehicle into the security and polling command post at the Doliba High School, knowing that the response units were still in Kundiawa. However, the situation was under control when the response units arrived. I directed the response units to round up the troublesome candidates. They were brought over and I sternly warned them that if they caused any more problems, they would be arrested when they came into Kundiawa for counting. We wanted to charge Michael Korry for damaging the school gate but the school principal requested payment instead.

There were insufficient numbers of response units to cover both LLG areas on the same day, so polling was conducted in Salt on the first day and Nomane on the second. Polling was conducted without any disruption; however, we witnessed widespread multiple voting due to inflated electoral rolls.

\section{Management issues}

The PPC provided the overall leadership of the combined forces during the election. It is at times difficult to manage a joint force of different disciplinary forces. In one instance, there was an armed confrontation between the PNGDF platoon and the local police personnel, when the PNGDF suspected that the local police were collaborating with some local candidates. Shots were fired by the PNGDF at the police and the general public and the situation looked tense. Fortunately, the PPC acted quickly and effectively and good working relations were restored. The PNGDF operation commander, Colonel Mae, and police operation commander Assistant Commissioner S. Kauba, were very supportive of the PPC who warned both the local police and the PNGDF that he would take disciplinary action against them if they failed to work together. He reiterated to both forces that he was the ultimate authority and that they were not to take matters into their own hands. The mutual working relationship was restored then and there. 


\section{What worked well and what did not}

While the overall security of the election process under police leadership depended heavily on the planning and deployment of security forces and polling staff, and the acquisition and distribution of equipment, the success of the 2007 national election could best be measured by the cooperative efforts of all agencies in achieving an outcome that has been acclaimed as 'successful' and 'better than 2002' - despite the many difficulties and criticisms, and complaints about the electoral roll, the number of polling places, poor communications, problems with finance and other issues.

Although there were some instances of bad behaviour or lack of action on the part of security forces, and incompetence or corruption in polling and counting situations, often attributable to lack of training, when looking at the deployment of some 1200 troops and up to 3000 election officials one might suggest that these incidents were isolated and that the cooperative partnership in fact contributed to a safe election.

The following security aspects of the election worked well:

- Cooperation between all agencies was very much improved.

- Planning, deployment and extraction of a large contingency of men and women into Chimbu Province was achieved despite lack of transport (helicopters and reliable vehicles).

- A better organized force with commitment to the elections and to the community was achieved.

- Election awareness was improved (although much more is needed in some provinces).

- The Provincial Steering Committee was coordinated well.

- Timely payment of allowances to police eliminated risks.

- Morale and discipline were high.

- Planning and delivery of fuel for air operations in the province was good.

- The use of provincial treasuries for the disbursement of funds by the PPC worked well.

- Counting was well conducted by PNGEC officials and security forces.

The following security aspects did not work well:

- Planning was done at headquarters in Port Moresby without considering the local setting of Chimbu Province.

- At times there was a lack of inter-agency communication on logistics. 
- An eleventh-hour request for air transport by the PNGEC to move people and election materials caused delays in operations.

- Post-election operations lacked manpower and funding.

- Finance was inadequate and too late.

- Provinces were unable to meet budgets, particularly in securing logistics.

- Road infrastructure into districts was really poor.

- Communication was a major problem at provincial level: there were no networks or integration; there were insufficient handheld radios where polling security was deployed, and without handheld radios no ground-toair contact; there had been no maintenance of police equipment, including repeaters, for 12 years.

- The cost of hire vehicles, which were often unsuitable and unreliable, was excessive.

- There was inadequate provincial funding to secure local transport: police fleets were run down, with no replacements for up to 15 years.

- Field uniforms: there was only one pair to each police officer so we could not get changed when it got wet.

- No protective clothing or equipment was provided for wet conditions, which prevailed in many areas.

- Training: many security personnel were unaware of their roles and responsibilities; further training was needed on election offences, and arrest and prosecution procedures.

- Many Correctional Services personnel were unaware of the LPV system.

The following electoral matters did not work well:

- The electoral roll was inflated or deflated and largely unused, with line-up voting widespread.

- Polling materials arrived late.

- There were delays in polling.

- Too many polling places in close proximity promoted multiple voting and caused problems with deployment of security.

- Polling places were moved against the advice of security forces, due to community pressure.

- Election officials and police were involved with candidates.

- PNGEC officials were not paid allowances, causing delays to the election process.

- There was a lack of awareness and training for polling officials.

- Returning officers and assistant returning officers lacked capacity to deal with electoral problems. 
- Widespread money politics was practiced by candidates.

- One-day polling in the Highlands did not work.

One of the major issues which affected both security and polling personnel was the exceptionally bad weather across the whole of Chimbu Province. As a result, polling places which had been deemed accessible by road during the planning phase were rendered accessible only by air. Further delays in some districts were caused because helicopters were busy extracting polling security from Western Highlands Province and were not available to insert personnel into Chimbu Province for polling to start on time. Moreover, when the helicopters became available there were further delays in some districts because the helicopters could not get off the ground due to the weather. This hampered the insertion of polling security and polling officials.

\section{Local issues which affect law and order at election time}

Compounding the existing law and order problems are local issues that come into play in the Highlands provinces at election time. These issues, which are deeply entrenched in the local political cultures, need to be critically addressed by government.

The haus lain (clan) has assumed paramount importance in local political culture, so much so that there is often consensus to corrupt the electoral process. Candidates think that it is their ultimate right to get all the votes from their own council ward. Individuals face intense pressure to vote along clan lines and the majority of voters think it is wrong to give their votes to candidates outside their clan. This is a part of Simbu political culture that the law cannot override. Unfortunately, though, it deprives people of their free will to vote for a candidate of their choice and denies their democratic right to a free and fair election.

Under LPV, candidates sought to control their own ward areas during polling so as to secure the first preference vote. At most of the polling booths I went to, candidates or their campaign managers were physically present to ensure that they got all the first preferences.

Many candidates also sought to influence polling by trying to shift gazetted polling locations to ungazetted locations in order to control the way people voted. Although this practice is illegal, polling stations in some parts of Chimbu were moved when presiding officers collaborated with the candidates. It was difficult for security personnel to stop this. Under law, the presiding officer is the designated authority at the polling station. Moreover, when security personnel 
attempt to intervene they put their safety at risk. The biggest deterrent to this sort of behaviour is a large security presence, and in locations where there was an adequate security presence, candidates and voters were controlled and this allowed for good polling. This corrupt and unacceptable behaviour needs to be addressed.

Though police are authorized to make arrests at election time, they are often powerless against local populations which are heavily armed. This is a serious constraint for the law-enforcing body. I personally encountered instances where illegal firearms were being carried around freely-particularly in the Salt and Nomane LLG areas - but felt unable to arrest people without risking my life.

During the polling I, and the security personnel under my command, witnessed numerous instances of multiple voting, candidates controlling polling booths, and other violations around polling areas, in all the districts of the province. For the most part, the security personnel deployed to polling stations were unarmed and so could not do much. We were also conscious of the need to avoid decisions that might put polling officials' and security personnel's lives at risk. Geography was a major concern, as most of the locations were remote and we knew it would be difficult for more security personnel to get in and assist if the situation got out of hand. Offences were committed by people who took advantage of the situation, knowing that we could not arrest them all. In SaltNomane multiple voting using inflated rolls was observed during polling. The response units were unable to contain the situation. We closed down only one polling station, at Ward 4, Salt LLG, and confiscated 200 ballot paper as all the eligible voters had voted. We arrested six people and took them to the command post where they admitted to multiple voting. But the location was remote and there was no transport to take them into Kundiawa to lay charges against them, so the suspects were cautioned and released back to the village.

\section{Aftermath of election violence}

For the most part, polling and counting in Chimbu was completed despite minor disturbances, two murders, and much multiple voting made possible by the inflated electoral roll. The 2007 election was widely seen to be a better election than previous national elections: no ballot boxes were destroyed, no polling booths over-run and no polling stations hijacked, as had happened in the past.

In part this can be attributed to LPV. Candidates and supporters did not want to endanger the ballot boxes and hence no ballot box was destroyed or disputed. Their concern was that if a ballot box was hijacked their opponent might well lose all 1st preferences but they might lose 2nd and 3rd preferences. This 
was one way in which the LPV system produced a better election. LPV also contributed to a more peaceful campaign period as there was more cooperation between candidates.

All around the province the people were happy that there was less violence during the campaign and polling periods. Nevertheless, violence erupted as the counting proceeded to its final stages for all the six electorates of Simbu and after the declaration of the open seats there was violence throughout the province. Losing candidates and their supporters or tribesmen started attacking innocent men, women and children who had not voted for them. They complained that they had paid voters but had not received promised support. Public servants and community leaders who had helped ensure a peaceful election process were also attacked and their property destroyed. One notable example was the burning down of Kaima and Munuma villages in Gumine District by a losing candidate and his supporters. Not only did they burn down houses, they destroyed food gardens and livestock.

School children were prevented from attending school, health centres were closed, and people were fearful of travelling into town, concerned that they might get attacked along the way. In Salt and Nomane where I had been stationed, bridges were dismantled and for four months people could not get into Kundiawa or Goroka.

These provocative acts by losing candidates and supporters angered people from opposing clans giving rise to full-scale tribal fights, which resulted in damage to local infrastructure and disrupted normal service delivery to the districts. Added to this, there were constant road blocks on all district roads and harassment of the travelling public by criminal elements taking advantage of the situation. Bridges were destroyed, depriving people of access to schools, health services, and police assistance. Government employees could not perform normal duties as a result of high tension and violence. The costs were immense.

Police in Papua New Guinea are often criticized for their slowness to respond when security incidents arise. Sometimes these complaints are warranted. But in Chimbu the Corrective Services personnel, reserve police, and auxiliary police from East Sepik were withdrawn after the completion of polling and the armed units (PNGDF and police mobile units) were withdrawn a week after counting, leaving only the provincial police to attend to the post-election violence. Thus, despite the huge security presence during polling there was limited capacity to respond to post-election violence. With limited personnel and resources at his disposal, and given the remoteness of some of the locations at which fighting broke out, the PPC focused on mediation processes in an effort restore peace to the warring communities. Provincial peace mediators (gazetted peace mediators that solve conflicts through a mediation process) and police personnel went into 
fighting zones and camped out, negotiating with tribal leaders for peace. All parties agreed to mediation, and those involved in the fighting were asked to lay down their weapons and let peace and normalcy prevail in their communities. The mediation process proved successful, as people realized that fighting would only cause pain and misery for themselves. They recognized, too, that the candidates who had incited the violence had returned to Moresby or other centres and were not the ones suffering. The success of mediation processes was an advance on the use of force previously relied upon by police.

The police mobile squads were originally established in the Highlands to respond to tribal fights. Over the years, however, they have lost their effectiveness, so that the use of force by police to stop tribal fighting has little impact in presentday Chimbu. In part this is because the public is equally or better armed. Instead, the police are now using restorative mediation approaches to solve tribal fights. These are proving far more successful. Mediation involving police, peace mediators, community leaders and representatives of warring tribes has been able to bring an end to tribal fights in Sinasina, Salt and Nomane. Table 7.3 provides some information on the tribal fights around Chimbu during the postelection period.

Table 7.3: Outcome of tribal fights in Chimbu Province

\begin{tabular}{lccl}
\hline District & $\begin{array}{c}\text { Number of } \\
\text { tribal fights }\end{array}$ & Dead & Police action \\
\hline Kerowagi & 5 & 4 & Peace mediation stopped all the fights \\
Sinasina-Yongomugl & 1 & 4 & Peace mediation stopped all the fights \\
Chuave & 1 & 2 & Peace mediation stopped all the fights \\
Gumine & 4 & 4 & Peace mediation stopped all the fights \\
Karamui-Nomane & 2 & 6 & Peace mediation stopped all the fights \\
Kundiawa-Gembogl & 1 & 3 & $\begin{array}{l}\text { Peace mediation stopped all the fights } \\
\text { (2 killed by police in self defence) }\end{array}$ \\
\hline
\end{tabular}

\section{Simbu administration and police actions to end violence}

The Chimbu police sought to involve the provincial administration in addressing the violence that emerged in the aftermath of the 2007 election. This proved difficult, compounded by the fact that the new government was not yet in place and public servants were not performing to expectations.

Some districts helped fund police operations in mediating peace. However, funding was delayed for more than a week; this hampered efforts in as much as police and mediation officials found it difficult to get into the fighting zones. In some of the districts, particularly Salt, Nomane and Karamui public servants did 
not help the police or involve themselves in the peace mediation process, which was undertaken by community leaders, peace mediators, and police. Generally, people in the communities involved in the peace process were frustrated at not being able to air their grievances to community leaders and government officials. They felt it was important to see government officials, church and community leaders, and police working hand-in-hand to address law and order issues in the communities and commended us for using community policing rather than heavy-handed tactics. The government should assist the people in restoring peace and order.

Prior to the 2007 election, people in Chimbu had come to see election violence as a normal part of their lives in the five-year election cycle. They had also come to expect that the police would respond to post-election violence with force. The 2007 election in Chimbu marks a watershed in police-community relations in that, despite limited manpower, the police responded effectively to post-election violence, opening dialogue and restoring peace and normalcy in the province. Tribal fighting has now stopped and the people have started to reclaim their lives.

\section{Community involvement in the election and election aftermath}

In the two years I have been working in Chimbu, I have found the people understanding and easy to negotiate with. They responded well to the awareness we provided and this helped in dealing with problems during and after the election. Community leaders and elders took the initiative in helping to organize their people and find solutions to their problems.

During the awareness period, local leaders helped to gather their constituents together to ensure a good attendance at every awareness session conductedthe awareness covered 80,000 people in three months. During the polling the leaders in most communities assisted by giving pre-polling speeches appealing for peace and calm during the polling in their respective ward areas. I am of the view that the election awareness helped create this beneficial partnership, because the police and leaders had had the opportunity to work together in the lead-up to the election. In some of the more remote areas people could not remember the last time police had visited.

In the aftermath of the election, police manpower was strained. Only four to six police personnel were deployed into each fighting zone to address the tribal conflict. In many cases the police deployed were the same police who had been involved in the pre-election awareness. Again, the community leaders 
and people welcomed us, listened to what we had to say, and helped restore peace and normalcy. For example, in Salt LLG area, where I had conducted awareness and was deployed as contingent commander, two tribes at Yobai were in the middle of a tribal fight when two policemen and I came into the area. We walked in unarmed, and were pleasantly surprised to find that the combatants laid down their weapons and withdrew back to their comfort zones. Personally, I was amazed. We visited both warring tribes and saw that they were still armed with weapons ranging from a semi automatic rifle and Bushmaster shotgun, to bows and arrows. Community leaders from the surrounding tribes came in to assist us in the peace negotiation, and the leaders from the warring clans controlled their men, paving the way for a peace settlement.

The people saw the law as a neutral body working for peace. They recognized that we were not there to support either of the conflicting parties. We chose to go into the war zone unarmed so as to indicate to the warring tribes that the police were there to help mediate peace.

\section{Conclusion}

Election 2007 has shown that partnerships between the police and the community are the way forward if we are to solve lawlessness in the Highlands. Community policing produces a win-win situation: it saves police time and resources and allows communities the space to give their views on how they want to make peace. As the communities know the root cause of the problems, they can suggest alternative ways to make peace in accordance with their traditional ways of solving conflicts. They are the people who will live in the communities and they want to see peace prevail for a long time for the good of their families.

The awareness we conducted yielded some impressive results. It reduced police work. It also resulted in fewer campaign houses and less corruption in some areas. Relationships built between police and community members helped in resolving problems during elections and in the post-election period. Understanding of the geography, through walking across the province doing awareness, proved invaluable for police when making logistical arrangements (especially as PNGEC officials did not always have this knowledge themselves). Much greater trust of police by community members, built through the awareness campaign, increased community respect for police and helped police sort out problems with the community during the election. Knowledge gained by the police through the ESP training and though the awareness, coupled with their past election experiences, helped individual officers in taking the initiative to step in when PNGEC officials were out of their depth. What Election 2007 
has shown is that joint electoral awareness is both essential and invaluable. The PNGEC needs support and good leadership to conduct elections and this can be provided in part by the security forces and the wider community.

In my view, the 2007 election in Chimbu was an improvement on past elections. But we must not rest on our laurels. Further civic and law and order awareness is needed and must be undertaken on an ongoing basis. We must look into the difficulties of enforcing election laws and further clarify the role of the police.

Security units, including mobile squads and the PNGDF, need to stay longer after elections to help respond to tribal fights. In Chimbu we were lucky because the good relations we had established in the lead-up to the election meant that post-election fighting could be brought under control quickly. Sadly this has not been the case in other parts of the Highlands. 